\title{
Effect of incentive spirometer exercise on pulmonary functions in children with spastic cerebral palsy
}

\author{
Mahmood Dhahir Al-Mendalawi(D)
}

To the Editor,

In their interesting case-control study, Elseify et al. [1] studied nicely the influence of incentive spirometer exercise (ISE) on the spirometry pulmonary function in Egyptian children with spastic cerebral palsy $(\mathrm{CP})$. They found significant improvements in forced expiratory volume at first second (FEV1\%), forced vital capacity (FVC $\%$ ), and maximal mid-expiratory flow in the study group, but not in the control group. Accordingly, they supported the beneficial use of ISE in enhancing lung functions in children with spastic CP [1]. It is explicit that spirometric equations (SE) are usually needed to precisely interpret the reading of various elements of pulmonary function tests in the clinical settings and research centers [2]. To achieve that task, many pediatric population-specific SE have been generated [3-5]. Regrettably, Elseify et al. [1] did not obviously state which pediatric SE they employed in the study methodology. Therefore, such methodological limitation might bring into question the study results.

Author's response

Dear Sir,

Thanks for your interest in our study Elseify et al.

This is regarding your concern about not mentioning the population-specific spirometric equations (SE) used in our study.

Although in the last years we were interestingly following the development of SE for different ethnicities, no studies have been done in Egypt for Egyptian-specific pediatric SE, and no studies worldwide were done to prove that there is a statistically significant difference between them in different ethnicities. So, all the studies in Egypt (not only our study) depend on commercially

Correspondence: mdalmendalawi@yahoo.com

Department of Paediatrics, Al-Kindy College of Medicine, University of Baghdad, P.O.Box 55302, Baghdad, Iraq available predictive values to detect the percentage of the predicted spirometric values that are done by the software of the spirometer device and not on SE.

Thanks!

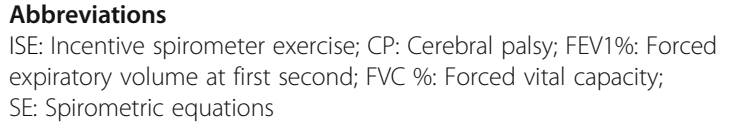

Acknowledgements

None

\section{Author's contributions}

Concept, design, literature review, preparation, and editing of manuscript.

The author(s) read and approved the final manuscript.

\section{Funding}

None

Availability of data and materials

Not applicable

Ethics approval and consent to participate

Not applicable

\section{Consent for publication}

Not applicable

\section{Competing interests}

The authors declare that they have no competing interests.

Received: 27 March 2020 Accepted: 21 May 2020

Published online: 29 June 2020

References

1. Elseify MY, Ramadan DA, Ishak SR. Effect of incentive spirometer exercise on pulmonary functions in children with spastic cerebral palsy. Egypt J Bronchol. 2019;13,Suppl 51:716-721.

2. Vogt B, Falkenberg C, Weiler N, Frerichs I (2014) Pulmonary function testing in children and infants. Physiol Meas 35:59-90

3. Ma YN, Wang J, Dong GH, Liu MM, Wang D, Liu YQ et al (2013) Predictive equations using regression analysis of pulmonary function for healthy children in Northeast China. PLoS One 8:e63875

4. Aristizabal-Duque R, Castiblanco E, Rodriguez I, Sossa-Briceño MP, Rodriguez-Martinez CE (2019) Reference values for spirometric parameters

\section{Springer Open}

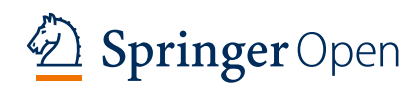

(c) The Author(s). 2020 Open Access This article is licensed under a Creative Commons Attribution 4.0 International License, which permits use, sharing, adaptation, distribution and reproduction in any medium or format, as long as you give appropriate credit to the original author(s) and the source, provide a link to the Creative Commons licence, and indicate if changes were made. The images or other third party material in this article are included in the article's Creative Commons licence, unless indicated otherwise in a credit line to the material. If material is not included in the article's Creative Commons licence and your intended use is not permitted by statutory regulation or exceeds the permitted use, you will need to obtain permission directly from the copyright holder. To view a copy of this licence, visit http://creativecommons.org/licenses/by/4.0/. 
in healthy children living in a Colombian city located at $2640 \mathrm{~m}$ altitude. Pediatr Pulmonol 54:886-893

5. Chang SM, Tsai HJ, Tzeng JY, Yeh KW, Chen LC, Lai SH et al (2019)

Reference equations for spirometry in healthy Asian children aged 5 to 18 years in Taiwan. World Allergy Organ J 12:100074

\section{Publisher's Note}

Springer Nature remains neutral with regard to jurisdictional claims in published maps and institutional affiliations.

\section{Submit your manuscript to a SpringerOpen ${ }^{\mathcal{O}}$} journal and benefit from:

- Convenient online submission

- Rigorous peer review

- Open access: articles freely available online

- High visibility within the field

- Retaining the copyright to your article

Submit your next manuscript at $\boldsymbol{\wedge}$ springeropen.com 